\begin{tabular}{|l|l|l||}
\hline \multicolumn{2}{|c|}{ PublisherInfo } \\
\hline \hline PublisherName & $:$ & Palgrave Macmillan UK \\
\hline \hline PublisherLocation & $:$ & London \\
\hline \hline PublisherImprintName & $:$ & Palgrave Macmillan \\
\hline
\end{tabular}

\title{
Civil service employment statistics 2006
}

\begin{tabular}{|l|l|l||}
\hline \multicolumn{2}{|c|}{ ArticleInfo } \\
\hline \hline ArticleDOI & $:$ & $10.1057 /$ palgrave.elmr.1410171 \\
\hline \hline ArticleCategory & $:$ & Feature \\
\hline \hline ArticleFirstPage & $:$ & 36 \\
\hline \hline ArticleLastPage & $:$ & 40 \\
\hline \hline & & $\begin{array}{l}\text { RegistrationDate }: 2007-11-16 \\
\text { OnlineDate } \quad: 2007-11-16\end{array}$ \\
\hline ArticleHistory & $:$ & Crown copyright2007 \\
\hline \hline ArticleCopyright & $:$ & \\
\hline \hline
\end{tabular}


Donna Livesey, Aff1

Craig Taylor, ${ }^{\text {Aff1 }}$

Pete Jones, ${ }^{\text {Aff1 }}$

\section{Presents a summary of annual statistics, previously produced by the Cabinet Office and now the responsibility of ONS.}

This article presents a summary of annual Civil Service statistics for the year ending 30 September 2006, as published in July 2007. Previously produced by the Cabinet Office, responsibility for the collection and publication of these statistics is now with the Office for National Statistics (ONS). This transfer of responsibility was outlined in an 'In brief' article in the February 2007 edition of Economic \& Labour Market Review. Quarterly Civil Service employment statistics are already published as part of the ONS Public Sector Employment First Release, and a work programme has been initiated to reconcile the annual and quarterly figures as much as possible. The annual Civil Service statistics provide a more detailed picture of characteristics of the Civil Service than do the quarterly figures.

Misc

The Full Text of this article can be found on the National Statistics website (http://www.statistics.gov.uk/elmr/11_07/downloads/elmr_oct07_livesey.pdf). 